\title{
STUDI PENYADAPAN GETAH PINUS CARA BOR DENGAN STIMULAN $\mathrm{H}_{2} \mathrm{SO}_{4}$ (Study of Pine Resin Tapping by Drilling Using $\mathrm{H}_{2} \mathrm{SO}_{4}$ Stimulant)
}

\author{
Mody Lempang \\ Balai Penelitian dan Pengembangan Lingkungan Hidup dan Kehutanan Makassar \\ Jl. Perintis Kemerdekaan Km. 16 Makassar 90243 \\ Telp. (0411) 554049 \\ E-mail:mlempang@yahoo.com
}

Diterima 31 Januari 2017, Direvisi 9 Mei 2017, Disetujui 22 Agustus 2017

\begin{abstract}
In general, pine resin yield is affected by various factors i.e. pine tree species, growing environment and tapping method. This paper studies pine resin tapping yield by drilling method using $\mathrm{H}_{2} \mathrm{SO}_{4}$ stimulant. Tapping point is designed in the depth of 4, 6 and $8 \mathrm{~cm}$ and sloping $25^{\circ}$. Three stimulant concentrations $(0,15 \%, 30 \%)$ were brushed in the tapping point and the treatments were repeated 10 times. Experimental design based on $3 \times 3$ factorials in completely randomized design. The first factor is the depth of drilling holes, the second factor is the concentration of $\mathrm{H}_{2} \mathrm{SO}_{4}$ stimulant used and reptition of 10 times. Pine resin yields were analyzed using analysis of variance and further test was conducted by honestly significant difference test. Results show that tapping pine by drilling and stimulant addition producedpine resin between 15.5 to 109.3 $\mathrm{g} /$ tree/ collection $(56.3 \mathrm{~g} /$ tree/ collection on average) or between 2.6 to $18.2 \mathrm{~g} /$ tree/day $(9.4 \mathrm{~g} /$ tree/ day on average). Pine resin yield is significantly influenced by drilling hole depth and $\mathrm{H}_{2} \mathrm{SO}_{4}$ stimulant concentrations. The deeper the drilling hole, the more pine resin yield, and the higher the concentration of $\mathrm{H}_{2} \mathrm{SO}_{4}$ stimulant the higherpine resin yield. Pine resin yield of $8 \mathrm{~cm}$ tapping depth is $65.96 \%$ bigher than $4 \mathrm{~cm}$ tapping depth, and 30\% $\mathrm{H}_{2} \mathrm{SO}_{4}$ improved the yield by about 56.45\%. The largest pine resin yield is achieved from tapping point of $8 \mathrm{~cm}$ depth and 30\% $\mathrm{H}_{2} \mathrm{SO}_{4}$ that yiled about 90.7 $\mathrm{g} /$ tree/collection in average.
\end{abstract}

Keywords: Pine resin, tapping, drilling method, $\mathrm{H}_{2} \mathrm{SO}_{4}$, stimulant

\begin{abstract}
ABSTRAK
Secara umum, produksi getah pinus dipengaruhi oleh beberapa faktor, yaitu jenis pohon pinus, lingkungan pertumbuhan, dan cara penyadapan getah. Tulisan ini mempelajari produksi getah pinus yang disadap dengan cara dibor dan menggunakan stimulan $\mathrm{H}_{2} \mathrm{SO}_{4}$. Lubang sadap dirancang dengan kedalaman 4, 6, dan $8 \mathrm{~cm}$ dengan kemiringan $25^{\circ}$. Tiga konsentrasi stimulan $\mathrm{H}_{2} \mathrm{SO}_{4}(0,15 \%, 25 \%)$ dilaburkan pada luka sadap dengan pengulangan perlakuan 10 kali. Penelitian dirancang menggunakan percobaan faktorial $3 \times 3$ dengan rancangan acak lengkap dan uji lanjutan uji beda nyata jujur. Hasil penelitian menunjukkan bahwa penyadapan getah pinus dengan cara dibor dan penambahan stimulan $\mathrm{H}_{2} \mathrm{SO}_{4}$ menghasilkan getah pinus antara 15,5-109,3 g/pohon/pungut (rata-rata 56,3 g/pohon/pungut) atau antara 2,6-18,2 g/pohon/hari (rata-rata 9,4 g/pohon/hari). Hasil getah pinus dipengaruhi secara nyata oleh kedalaman lubang sadap dan konsentrasi stimulan $\mathrm{H}_{2} \mathrm{SO}_{4}$. Semakin dalam lubang sadap, semakin banyak getah pinus yang dihasilkan, demikian juga semakin tinggi konsentrasi stimulan $\mathrm{H}_{2} \mathrm{SO}_{4}$ yang digunakan semakin banyak getah pinus yang dihasilkan. Produksi getah pinus pada lubang sadap 8 cm lebih tinggi 65,96\% dari lubang sadap $4 \mathrm{~cm}$ dan penggunaan stimulan $\mathrm{H}_{2} \mathrm{SO}_{4} 30 \%$ meningkatkan produksi getah pinus sebesar 56,45\%. Produksi getah terbanyak diperoleh dari titik sadap $8 \mathrm{~cm}$ dengan $30 \% \mathrm{H}_{2} \mathrm{SO}_{4}$ dengan hasil getah rata-rata $90,7 \mathrm{~g} /$ pohon/pungut.
\end{abstract}

Kata kunci: Getah pinus, penyadapan, dibor, $\mathrm{H}_{2} \mathrm{SO}_{4}$, stimulan 


\section{PENDAHULUAN}

Hutan menyediakan banyak manfaat bagi kehidupan manusia, antara lain manfaat hasil hutan berupa kayu dan bukan kayu. Pemanfaatan hasil hutan bukan kayu (HHBK) bertujuan selain untuk meningkatkan kesejahteraan masyarakat juga untuk mengoptimalkan sumberdaya hutan itu sendiri. Industri HHBK pada umumnya bersifat padat karya dan tidak memerlukan teknologi yang canggih, tetapi mampu menghasilkan produk yang bernilai ekonomi tinggi serta ramah lingkungan (Waluyo, Wahyudi, \& Santoso, 2012). Jumlah dari semua kelompok HHBK sebanyak 557 jenis. Namun, yang sudah berkembang dan mendapat perhatian dari pemerintah maupun pengusaha masih terbatas pada sepuluh jenis yang merupakan HHBK unggulan nasional, yaitu: gondorukem, bambu, arang, kemiri, getah jelutung, gambir, sutera alam, lebah madu, gaharu, dan rotan (Suharisno, 2009); (Hani, 2009). Salah satu HHBK yang bernilai komersial dan potensial untuk dikembangkan saat ini adalah getah pinus. Getah pinus adalah salah satu HHBK yang bernilai komersial dan potensial untuk dikembangkan saatini.

Getah pinus merupakan hasil eksudat dari pohon yang tergolong dalam marga Pinus pada umumnya dan khususnya jenis Pinus merkusii Jungh. \& de Vriese. Getah pinus mulai disadap sejak abad 15 di Amerika dan digunakan untuk menambal perahu yang retak atau bocor (Satil, Selvi, \& Polat, 2011). Penyadapan pinus merupakan kegiatan yang cocok bagi negaranegara yang memiliki tegakan pinus untuk menghasilkan biomassa getah yang memberikan manfaat ekonomi dan sosial (Rodrigues-Corrêa, Apel, Henriques, \& Fett-Neto, 2011). Di masa silam, penyadapan getah pinus merupakan sumber pendapatan mendasar bagi masyarakat pedesaan di seluruh dunia (Nanos, Tadesse, Montero, Gil, \& Alia, 2001).

Pada pengolahan getah pinus dengan cara destilasi diperoleh gondorukem sebagai residu dan produk tambahan berupa destilat yang disebut minyak terpentin (Kasmudjo, 2010). Produk gondorukem digunakan pada berbagai bidang industri antara lain kertas, sabun, detergen, kosmetik, cat, vernis, semir, perekat, karet, insektisida, dan desinfektan, sedangkan terpentin digunakan dalam industri parfum, farmasi, kimia, desinfectant dan denaturant (Satil et al., 2011); (Sharma \& Lecha, 2013). Produk turunan dari getah pinus sebagai salah satu jenis HHBK sudah masuk dalam sistem perdagangan internasional. Perdagangan getah pinus (gondorukem dan terpentin) Indonesia di pasar internasional menempati urutan ketiga setelah China dan Brasil (Bina, 2014). Sebagai produsen derivat gondorukem dan terpentin urutan ketiga, Indonesia melalui Perum Perhutani mampu menembus $10 \%$ total produksi dunia setelah China (70\%) dan Brasil (11\%). Produksi getah pinus Indonesia berkisar 900.000 ton/tahun dan yang diperdagangkan di pasar getah internasional mencapai 50.000 - 60.000 ton/tahun (Bina, 2012). Negara tujuan ekspor produk getah pinus Indonesia antara lain Eropa, India, Korea Selatan, Jepang dan Amerika (Perhutani, 2011). Sehubungan dengan tingginya harga gondorukem dan terpentin di pasar internasional, beberapa tahun belakangan ini Perum Perhutani melakukan penyadapan getah pinus secara intensif '(Sukarno, Hardianto, Marsoem, \& Naiem, 2015). Harga derivat gondorukem pada tahun 2014 antara US\$ 2.000 - US\$ 4.000 per ton dan bahkan ada yang mencapai US\$15.000 per ton(Bina, 2014).

Produksi getah pinus di Indonesia tidak hanya dimonopoli oleh Perum Perhutani yang mengelola hutan di Pulau Jawa. Perusahaan swasta dan BUMN juga telah melakukan pengelolaan hutan pinus untuk memproduksi getah, misalnya di Sulawesi dengan areal hutan pinus 130.000 ha dan di Sumatera 335.000 ha (Santosa, 2010). Belakangan ini, dalam pelaksanaan penyadapan getah pinus secara komersial dilakukan dengan cara melukai kulit batang dan jaringan di bawahnya yang disertai dengan atau tanpa penggunaan stimulan kimia (Rodrigues-Corrêa, Lima, \& FettNeto, 2017). Dalam kegiatan pemanenan getah pinus di Indonesia telah dicoba beberapa cara penyadapan, antara lain cara koakan (quarre), cara kopral (riil) dan cara bor dengan menggunakan atau tanpa menggunakan stimulan (cairan perangsang). Seiring perkembangan ilmu pengetahuan dan teknologi serta pengalaman kerja di lapangan, teknik penyadapan pinus terus mengalami pembaharuan. Orientasi pembaharuan cara penyadapan bertujuan untuk meningkatkan produksi getah seoptimal mungkin namun tetap memperhatikan kelestarian baik produk getah pinus maupun pohon pinus sebagai 
penghasilnya (Sukadaryati., 2014). Penyadapan pinus dengan cara bor merupakan sistem penyadapan yang bersifat tertutup dengan luka sadap yang lebih dalam, sehingga dapat meningkatkan selain kuantitas juga kualitas hasil getah. Sedangkan penggunaan stimulan cairan asam pada luka sadap akan mengencerkan getah atau memperlancar alirannya dari dalam batang pinus, sehingga kuantitas hasil getah meningkat. Tulisan ini mempelajari penyadapan getah pinus cara bor dengan menggunakan stimulan $\mathrm{H}_{2} \mathrm{SO}_{4}$ yang dilakukan pada tegakan pinus hasil tanaman reboisasi di Kabupaten Tana Toraja, Provinsi Sulawesi Selatan.

\section{BAHAN DAN METODE}

\section{A. Lokasi dan Waktu Penelitian}

Penelitian dilaksanakan pada tahun 2006 di kawasan hutan produksi terbatas Kecamatan Mengkendek, Kabupaten Tana Toraja, Provinsi Sulawesi Selatan. Petak coba berada pada ketinggian $\pm 850 \mathrm{~m}$ dari permukaan laut.

\section{B. Bahan dan Alat}

Dalam pelaksanaan penelitian digunakan bahan antara lain: tegakan pinus (Pinus merkusii Jungh. \& de Vriese) hasil tanaman reboasasi kelas umur VI (umur 29 tahun) dengan diameter batang antara $25-45 \mathrm{~cm}$ dan belum pernah disadap, pipa paralon diameter 6/8" $(1,9 \mathrm{~cm})$, kantong plastik $7 \mathrm{~cm} \times 18 \mathrm{~cm}$, tali plastik (rafia) label plastik, label kertas, paku, stimulan $\mathrm{H}_{2} \mathrm{SO}_{4}$ (cairan asam sulfat/CAS) konsentrasi 15\% dan 30\%. Sementara alat yang digunakan terdiri dari: Generator 1000 watt, kabel listrik panjang $\pm 20 \mathrm{~m}$, bor listrik 750 watt, mata bor kayu 6/8" $(1,9 \mathrm{~cm})$, timbangan analitik, meteran pita, altimeter, parang, palu, gunting, botol plastik, sikat gigi (bekas), dan alat tulis menulis.

\section{Metode Penelitian}

\section{Pembuatan stimulan}

Sebelum penyadapan getah pinus dimulai, stimulan (cairan asam sulfat/CAS) dipersiapkan lebih dulu. Stimulan dibuat dari $\mathrm{H}_{2} \mathrm{SO}_{4}$ dengan kepekatan 98\% yang diencerkan dengan air $\left(\mathrm{H}_{2} \mathrm{O}\right)$ dengan menggunakan formula sebagai berikut:

$\mathrm{N}_{1} \mathrm{~V}_{1}=\mathrm{N}_{2} \mathrm{~V}_{2}$

keterangan:

$\mathrm{N}_{1}=$ kepekatan $\mathrm{H}_{2} \mathrm{SO}_{4}(98 \%)$

$\mathrm{V}_{1}=$ volume $\mathrm{H}_{2} \mathrm{SO}_{4}$ teknis yang dibutuhkan

$\mathrm{N}_{2}=$ kepekatan/konsentrasi stimulansia yang diinginkan (15\% atau 30\%)

$\mathrm{V}_{2}=$ volume air yang digunakan untuk mengencerkan.

Stimulan $\mathrm{H}_{2} \mathrm{SO}_{4}$ dengan konsentrasi $15 \%$ dan $30 \%$ yang sudah dibuat masing-masing ditempatkan dalam wadah (botol) plastik secara terpisah.

\section{Prosedur penyadapan}

Pembuatan luka sadap dimulai dari bagian pangkal batang ( $\pm 20 \mathrm{~cm}$ di atas tanah), luka sadap berbentuk lubang bor diameter 1,9 cm (6/8") dengan kedalaman $4 \mathrm{~cm}, 6 \mathrm{~cm}$, dan $8 \mathrm{~cm}$ (sesuai perlakuan). Untuk memudahkan getah mengalir dari dalam batang pohon ke dalam wadah penampung getah (kantong plastik) melalui saluran getah (pipa paralon yang berdiameter 1,9 $\mathrm{cm}$ dan panjang $6 \mathrm{~cm}$ ), maka lubang sadap tersebut dibuat miring dari luar (kulit batang) ke arah atas menuju pusat batang (empulur) dengan sudut kemiringan $25^{\circ}$. Pada pohon pinus yang disadap tanpa menggunakan stimulan, pemasangan pipa paralon langsung dilakukan setelah lubang sadap dibuat dengan panjang pipa 1 $\mathrm{cm}$ masuk ke dalam lubang bor. Sedangkan pada pohon pinus yang disadap menggunakan stimulan, luka sadap pada setiap lubang bor dioleskan sebanyak sekitar $1 \mathrm{ml}$ per lubang bor (luka sadap).

Pemberian stimulan pada luka sadap dilakukan dengan cara dilabur menggunakan sikat gigi. Setelah luka sadap diberi stimulan, kemudian diikuti dengan pemasangan pipa paralon (saluran getah). Pada ujung luar pipa paralon dipasang/digantung kantong plastik ukuran $7 \mathrm{~cm}$ x $18 \mathrm{~cm}$ (wadah penampung getah) dan ujung kantong diikat pada pipa paralon menggunakan rafia Pengikatan kantong plastik/penampung getah pada pipa paralon dimaksudkan agar kantong penampung getah tersebut tidak jatuh dan getah yang tertampung tidak tercampur kotoran dan air hujan pada saat penyadapan berlangsung. Pengunduhan (pengumpulan) hasil 
getah dan pembuatan lubang baru dilakukan setiap periode 6 hari. Pembuatan lubang bor baru dilakukan melingkar batang (horizontal), jumlah lubang melingkar batang sebanyak 3 buah dan jarak antara lubang bor $20-25 \mathrm{~cm}$. Setelah lubang bor melingkar batang mencapai 3 buah, maka pembuatan lubang berikutnya dilakukan ke arah atas batang (vertikal) dengan jarak antara lubang $15 \mathrm{~cm}$. Hasil getah yang telah dikumpulkan dalam setiap kantong penampung ditimbang beratnya menggunakan timbangan analitik.

\section{Rancangan percobaan}

Penelitian ini dilaksanakan menggunakan percobaan faktorial $3 \times 3$ dengan rancangan dasar RAL (rancangan acak lengkap). Faktor pertama adalah kedalaman lubang bor (faktor A) pada batang pinus yang terdiri dari tiga taraf kedalaman, yaitu $4 \mathrm{~cm}$ (a1), $6 \mathrm{~cm}$ (a2) dan $8 \mathrm{~cm}$ (a3). Faktor kedua adalah penggunaan stimulan $\mathrm{H}_{2} \mathrm{SO}_{4}$ (faktor B) yang terdiri dari tiga taraf konsentrasi, yaitu tanpa menggunakan stimulan (b1), menggunakan stimulan 15\% (b2) dan stimulan 30\% (b3). Dengan demikian terdapat 9 kombinasi perlakuan yang masing-masing diulang sebanyak 10 kali, sehingga jumlah pohon yang disadap sebanyak 90 . Pembuatan lubang bor dan pengumpulan getah pada setiap pohon dilakukan sebanyak 10 kali, sehingga jumlah hasil getah yang dikumpulkan sebanyak 900 kantong. Model statistik untuk percobaan faktorial yang terdiri dari dua faktor dengan menggunakan rancangan dasar RAL (Gaspersz, 1991) adalah:

$$
\mathrm{Y}_{\mathrm{i} \mathrm{j} k}=\mu+\mathrm{A}_{\mathrm{i}}+\mathrm{B}_{\mathrm{j}}+(\mathrm{AB})_{\mathrm{ij}}+\mathrm{E}_{\mathrm{ij} \mathrm{k}}
$$

keterangan:

$\mathrm{Y}_{\mathrm{i} \mathrm{k}}=$ Nilai pengamatan pada satuan percobaan ke-k yang memperoleh kombinasi perlakuan ij (taraf ke-i dari faktor A dan taraf ke-j dari faktor B)

$\mu \quad=$ Nilai tengah populasi (rata-rata yang sesungguhnya)

$\mathrm{A}_{\mathrm{i}} \quad=$ Pengaruh aditif taraf ke-i dari faktor $\mathrm{A}$ (lubang bor)

$\mathrm{B}_{\mathrm{j}} \quad=$ Pengaruh aditif taraf ke- $\mathrm{j}$ dari faktor $\mathrm{B}$ (stimulansia $\mathrm{H}_{2} \mathrm{SO}_{4}$ )

$(\mathrm{AB})_{\mathrm{ij}}=$ Pengaruh interaksi taraf ke-i faktor A dan taraf ke-j faktor B

$\mathrm{E}_{\mathrm{i} \mid \mathrm{k}} \quad=$ Pengaruh galat dari satuan percobaan ke-k yang memperoleh kombinasi perlakuan ij.

\section{Analisis Data}

Untuk mengetahui pengaruh dari masingmasing perlakuan terhadap hasil getah pinus, maka dilakukan analisis keragam (ANOVA, Analysis of Variance). Apabila terdapat perbedaan diantara perlakuan, $\mathrm{F}_{\text {hitung }}>\mathrm{F}_{\text {tabel }}$ analisis dilanjutkan dengan uji beda nyata jujur (HSD, Honestly Significant Difference Test) (Gaspersz, 1991).

\section{HASIL DAN PEMBAHASAN}

Getah yang dihasilkan pohon Pinus merkusii digolongkan sebagai oleoresin yang merupakan cairan asam-asam resin dan terpentin yang menetes keluar apabila saluran resin (resin canal) baik pada bagian kulit maupun bagian kayu pohon tersayat atau pecah. Penyadapan tegakan pinus (P. merkusii) kelas umur VI di kawasan hutan produksi terbatas Kecamatan Mengkendek Kabupaten Tana Toraja yang dilakukan dengan cara bor dan menggunakan stimulan $\mathrm{H}_{2} \mathrm{SO}_{4}$ diperoleh rata-rata hasil getah pinus (rata-rata dari 10 kali pemungutan) seperti disajikan pada Tabel 1.

Pada Tabel 1 dapat dilihat bahwa getah pinus yang dihasilkan bervariasi antara 38,3-90,7 $\mathrm{g} /$ pohon/pungut dengan rata-rata 56,3 $\mathrm{g} /$ pohon/pungut (rata-rata 9,4 g/pohon/ hari). Untuk mengetahui bagaimana pengaruh kedalaman lubang bor dan konsentrasi stimulan terhadap hasil getah pinus, maka dilakukan analisis keragaman (Anova) seperti pada Tabel 2.

Pada Tabel 2 ditunjukkan bahwa baik perlakuan kedalaman lubang bor maupun penggunaan stimulan $\mathrm{H}_{2} \mathrm{SO}_{4}$ berpengaruh sangat nyata terhadap hasil getah pinus, akan tetapi interaksi kedua perlakuan tersebut berpengaruh tidak nyata. Hal ini didukung oleh hasil penelitan (Sukarno, Hardianto, Marsoem, \& Naiem, 2013) bahwa ukuran lubang bor berpengaruh nyata terhadap hasil getah pinus. Dijelaskan juga oleh (Cahyono, Prakosa, Yuliantoro, \& Siswo, 2011) bahwa luas bidang luka sadap berpengaruh nyata terhadap hasil getah pinus.

Selain lubang bor, penggunaan stimulan $\mathrm{H}_{2} \mathrm{SO}_{4}$ juga berpengaruh sangat nyata terhadap hasil getah pinus. Produktivitas getah dipengaruhi oleh faktor pemberian stimulan (Santosa, 2010); 
Tabel 1. Rata-rata hasil getah pinus pada setiap perlakuan penyadapan (g/pohon/pungut) Table 1. Pine resin yield average in each tapping treatment (g/tree/collection)

\begin{tabular}{ccccc}
\hline \multirow{2}{*}{$\begin{array}{c}\text { Kedalaman lubang bor } \\
\text { (Depth of borholes) }\end{array}$} & \multicolumn{3}{c}{$\begin{array}{c}\text { Konsentrasi stimulan } \mathbf{H}_{2} \mathbf{S O}_{4} \\
\text { (Concentration of } \mathbf{H}_{2} \mathbf{S O}_{4} \text { stimulant) }\end{array}$} & $\begin{array}{c}\text { Rata-rata } \\
\text { (Average) }\end{array}$ \\
\cline { 2 - 4 } & $\mathbf{0} \%$ & $\mathbf{1 5 \%}$ & $\mathbf{3 0}$ & \\
\hline $4 \mathrm{~cm}(\mathrm{a} 1)$ & $\mathbf{( b 1 )}$ & $\mathbf{( b 2 )}$ & $\mathbf{( b 3 )}$ & \\
\hline $6 \mathrm{~cm} \mathrm{(a2)}$ & 38,3 & 42 & 47,4 & 42,6 \\
$8 \mathrm{~cm}(\mathrm{a} 3)$ & 42 & 59,1 & 65,7 & 55,6 \\
\hline Rata-rata (Average) & 50 & 71,6 & 90,7 & 70,8 \\
\hline
\end{tabular}

Tabel 2. Anova pengaruh lubang bor dan stimulan $\mathrm{H}_{2} \mathrm{SO}_{4}$ terhadap hasil getah pinus Table 2. Anova the effect of drilling hole and $\mathrm{H}_{2} \mathrm{SO}_{4}$ stimulant into pine resin production

\begin{tabular}{|c|c|c|c|c|c|c|}
\hline \multirow[t]{2}{*}{$\begin{array}{l}\text { Sumber keragaman } \\
\text { (Source of variance) }\end{array}$} & \multirow[t]{2}{*}{$\begin{array}{l}\mathrm{DB} \\
(D F)\end{array}$} & \multirow[t]{2}{*}{$\begin{array}{l}\mathrm{JK} \\
(S S)\end{array}$} & \multirow[t]{2}{*}{$\begin{array}{c}\mathrm{KT} \\
(M S)\end{array}$} & \multirow[t]{2}{*}{$\begin{array}{l}\text { F. hit. } \\
\text { (F. calc.) }\end{array}$} & \multicolumn{2}{|c|}{$\begin{array}{c}\text { F. tabel } \\
\text { (F. table })\end{array}$} \\
\hline & & & & & 0,05 & 0,01 \\
\hline Perlakuan (Treatments) & 8 & $23.657,158$ & & & & \\
\hline A & 2 & $9.081,6127$ & $4.540,8064$ & $8,61 * *$ & 3,11 & 4,88 \\
\hline B & 2 & $11.953,2607$ & $5.976,6304$ & $11,33^{* *}$ & 3,11 & 4,88 \\
\hline Interaksi (Interaction) AB & 4 & $2.622,2847$ & 655,5712 & $1,24^{\mathrm{tn}}$ & 2,48 & 3,56 \\
\hline Galat (Error) & 81 & $42.718,758$ & 527,3921 & & & \\
\hline Total & 89 & $66.375,916$ & & & & \\
\hline
\end{tabular}

Keterangan (Remark): $* *=$ Berbeda sangat nyata (Highly-significant difference)

${ }^{\mathrm{tn}}=$ Berbeda tidak nyata (Non-significant difference)

(Sharma \& Lecha, 2013). Menurut (Mirov, 1962) getah pinus (oleoresin) dapat dipisahkan ke dalam dua komponen, yaitu rosin dan turpentin. Rosin mengandung terutama asam-asam rosin dan sejumlah kecil unsur yang berbeda dari asam-asam rosin yang disebut resen. Turpentin adalah bahan kimia yang tidak murni, umumnya mengandung unsur hidrokarbon siklik atau terpen yang hampir selalu tercampur dengan unsur sesquiterpen dan kadang-kadang dengan unsur bukan terpen. Kompisisi kimia getah pinus dari Jawa Barat dianalisa kedalalam fraksi netral dan fraksi asam, dan ditemukan bahwa senyawa ini terdiri dari 50 - 53\% fraksi asam (Wiyono, Tachibana, \& Tinambunan, 2006). Fraksi netral pada dasarnya sama dengan terpentin yang disusun terutama oleh a-pinene, D-3-carene dan $\beta$-pinene. Sedangkan gondorukem (rosin) didominasi oleh fraksi asam dan sedikit fraksi netral. Fraksi asam dari gondorukem terutama disusun oleh abietic acid, palustric acid, dan neoabietic acid.

Asam-asam resin adalah unsur tidak stabil yang mudah berubah dan terisomerisasi dengan perlakuan panas dan asam kuat serta memiliki sifat mudah teroksidasi (Haris, 1948). Oleh karena itu, penggunaan cairan asam sulfat $\left(\mathrm{H}_{2} \mathrm{SO}_{4}\right)$ sebagai stimulan pada luka sadap akan mengencerkan cairan asam-asam resin dari getah pinus yang mengalir dari dalam batang, sehingga tidak cepat mengental/menggumpal dan menyumbat saluran getah yang terdapat pada luka sadap, akibatnya getah pinus mengalir lebih lama dan lebih banyak. 


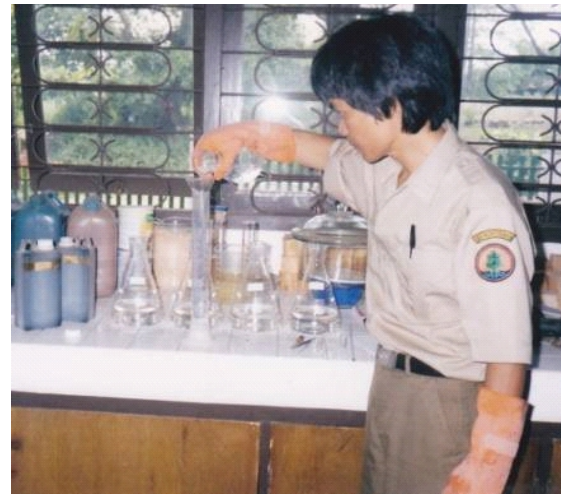

A

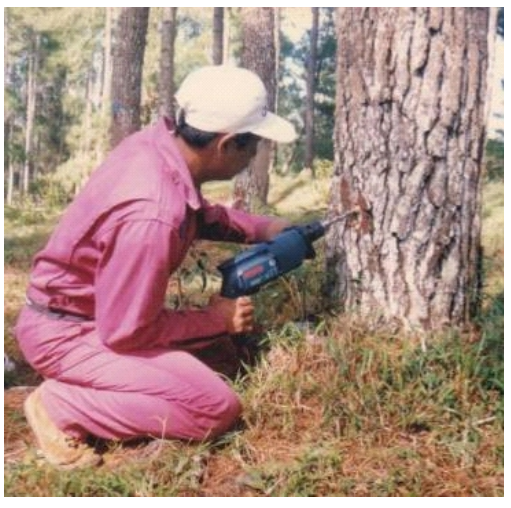

B

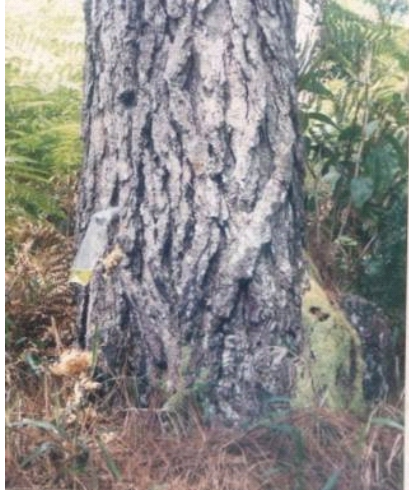

C

Gambar1. Proses penyadapan getah pinus: Menyiapkan stimulan $\mathrm{H}_{2} \mathrm{SO}_{4}$ (A), membuat lubang bor pada batang pinus (B) dan menampung getah pinus dalam kantong plastik (C)

Figure 1. Tapping process of pine resin: Prepering stimulant of $\mathrm{H}_{2} \mathrm{SO}_{4}(\mathrm{~A})$, making of drilling hole on pine steem $(B)$ and Collecting ofpine resin in plastic bag $(C)$

(Sharma \& Lecha, 2013) menjelaskan bahwa stimulan berbahan dasar asam kuat $\left(\mathrm{H}_{2} \mathrm{SO}_{4}\right)$ menyebabkan produksi getah meningkat setiap kali pengunduhan karena dapat memperlama waktu pengaliran getah dengan cara mereduksi tekanan turgor (turgensis) dalam sel epithel dan mencegah terjadinya kristalisasi resin serta pembentukan tylosoid. Pengaruh penggunaan stimulan dari asam kuat pada hasil getah dalam penyadapan pinus sebelumnya juga telah dijelaskan oleh (Kasmudjo, 1992) bahwa penggunaan stimulan asam dapat menyebabkan terbukanya saluran getah yang menyempit atau tersumbat melalui proses penghangatan asam. Akibatnya, saluran getah dan sel-sel parenkim terhidrolisis, tekanan menurun, cairan sel keluar sehingga getah menjadi lebih encer dan lebih lama keluarnya.
Karena perlakuan lubang bor berpengaruh sangat nyata pada hasil getah pinus, maka dilakukan uji $\mathrm{BNJ}_{0,01}$ rata-rata hasil getah pinus pada perlakuan lubang bor seperti disajikan pada Tabel 3 .

Hasil uji BNJ rata-rata hasil getah pinus pada perlakuan kedalaman lubang bor (Tabel 3) menunjukkan bahwa semakin dalam lubang bor semakin banyak hasil getah pinus. Hasil getah pinus rata-rata pada perlakuan kedalaman lubang bor antara $4 \mathrm{~cm}$ (a1) dengan $8 \mathrm{~cm}$ (a3) berbeda sangat nyata. Sedangkan hasil getah pinus pada perlakuan kedalaman lubang bor antara $4 \mathrm{~cm}$ (a1) dengan $6 \mathrm{~cm}$ (a2) dan antara $6 \mathrm{~cm}$ (a2) dengan 8 $\mathrm{cm}$ (a3) berbeda tidak nyata. Peningkatan kedalaman lubang bor dari $4 \mathrm{~cm}$ menjadi $6 \mathrm{~cm}$ meningkatkan hasil getah pinus sebesar 30,52\% dan dari $4 \mathrm{~cm}$ menjadi $8 \mathrm{~cm}$ meningkatkan hasil

Tabel3. Uji beda nyata jujur (BNJ) rata-rata hasil getah pinus pada perlakuan lubang bor Table 3. Honestly significant difference (HSD) test on average of pine resin yield at drilling hole treatment

\begin{tabular}{ccc}
\hline $\begin{array}{c}\text { Kedalaman lubang bor } \\
\text { (Depth of } \text { drilling holes })\end{array}$ & $\begin{array}{c}\text { Rata-rata, g/pohon/pungut } \\
\text { (Average, } \text { g/tree/collection) }\end{array}$ & $\begin{array}{c}\text { BNJ } 0,01 \\
\left(\text { HSD }_{\boldsymbol{0 . 0 1}}\right)\end{array}$ \\
\hline a1 & $42,6 \mathrm{a}$ & 20,92 \\
a2 & $55,6 \mathrm{ab}$ & \\
a3 & $70,8 \mathrm{~b}$ & \\
\hline
\end{tabular}

Keterangan (Remark): Angka-angka yang diikuti oleh huruf yang sama berbeda tidak nyata (Numbers followed by the same alphabed are not significant difference) 
getah pinus sebesar 65,96\%. Penelitian (Sukarno et al., 2013) juga menemukan bahwa semakin meningkat ukuran bor hasil getah juga semakin meningkat. Saluran resin (getah pinus) adalah rongga antar sel yang dikelilingi oleh sel-sel parenkim yang mengeluarkan resin ke dalam saluran (Shmulsky \& Jones, 2011). Seluruh lapisan yang mengelilingi saluran resin dan mengeluarkan resin disebut sel epitel (Harun, 2016). Pada kayu daun jarum terdapat dua bentuk saluran getah, yaitu saluran normal dan traumatis. Pembentuk saluran resin traumatis sehubungan dengan pelukaan atau kejadian traumatis pada pohon (Shmulsky \& Jones, 2011). Pelukaan pada kayu pinus akan mengeluarkan resin melalui luka dan mungkin diikuti oleh pembentukan sel-sel baru yang menghasilkan resin di sekitar luka. Pembuatan lubang bor yang lebih dalam menyebabkan bidang luka sadap semakin luas, jumlah saluran getah yang putus semakin banyak dan sel epitel lebih banyak terbentuk, sehingga hasil getah semakin banyak. Dijelaskan oleh Mirov (1962) bahwa pada pohon pinus yang pertumbuhannya normal, getah ditemukan terutama pada bagian kayu teras (heartwood). Hal ini sesuai dengan hasil penelitian Esteban, Gasson, Climent, Palacios, dan Guindeo (2005) yang menemukan bahwa kayu teras pada Pinus canariensis mengandung resin yang sangat tinggi. Oleh karena itu, perlakuan lubang bor yang lebih dalam pada penyadapan getah pinus akan menyebakan lebih banyak bagian kayu teras yang terluka, sehingga getah yang mengalir semakin banyak.

Selain perlakuan lubang bor, penggunaan stimulansia $\mathrm{H}_{2} \mathrm{SO}_{4}$ juga berpengaruh sangat nyata pada hasil getah pinus. Hasil uji $\mathrm{BNJ}_{0,01}$ rata-rata hasil getah pinus pada perlakuan stimulan $\mathrm{H}_{2} \mathrm{SO}_{4}$ disajikan pada Tabel 4.

Tabel 4 menunjukkan bahwa semakin tinggi konsentrasi stimulan $\mathrm{H}_{2} \mathrm{SO}_{4}$ yang digunakan semakin banyak hasil getah pinus. Hasil getah pinus berbeda sangat nyata pada penyadapan antara tanpa stimulan (b1) dengan menggunakan stimulan 30\% (b3). Walaupun demikian hasil getah pinus berbeda tidak nyata pada penyadapan antara tanpa stimulan (b1) dengan menggunakan stimulan 15\% (b2) dan antara menggunakan stimulan 15\% (b2) dengan 30\% (b3). Jika penyadapan tanpa stimulan dibandingkan dengan menggunakan stimulan, maka penggunaan stimulan dengan konsentrasi 15\% meningkatkan hasil getah pinus sebesar 32,72\% dan konsentrasi $30 \%$ meningkatkan hasil getah pinus sebesar $56,45 \%$. Hasil penelitian Sukadaryati. dan Dulsalam (2015) menunjukan bahwa penggunaan stimulan $\mathrm{H}_{2} \mathrm{SO}_{4}$ pada penyadapan getah pinus dengan cara koakan di RPH Cimanggu dan Majalengka Jawa Tengah dapat meningkatkan hasil getah 31,45\% dibandingkan dengan kontrol, sedangkan dengan menggunakan stimulan cuka kayu dapat meningkatkan hasil getah 14,61\%.

Walapun penggunaan stimulan $\mathrm{H}_{2} \mathrm{SO}_{4}$ dari konsentrasi $15 \%$ menjadi $30 \%$ dapat meningkatkan hasil getah pinus sebesar $23,73 \%$, namun konsentrasi 30\% dipandang kurang aman baik terhadap penyadap maupun tegakan pinus yang disadap. Hampir seluruh areal Perhutani menggunakan stimulan yang dibuat dari asam kuat $\mathrm{H}_{2} \mathrm{SO}_{4}$ dalam penyadapan getah pinus dengan konsentrasi yang bervariasi tergantung pada ketinggian tempat penyadapan(Sukadaryati,

Tabel 4. Uji beda nyata jujur (BNJ) rata-rata hasil getah pinus pada perlakuan stimulan $\mathrm{H}_{2} \mathrm{SO}_{4}$

Table 4. Honestly significant difference (HSD) test on average of pine resin yield at $\mathrm{H}_{2} \mathrm{SO}_{4}$ stimulant treatment

\begin{tabular}{ccc}
\hline $\begin{array}{c}\text { Konsentrasi stimulansia } \mathrm{H}_{\mathbf{2}} \mathrm{SO}_{4} \\
\text { (Concentration of } \mathbf{H}_{\mathbf{2}} \mathbf{S O}_{4} \text { stimulant) }\end{array}$ & $\begin{array}{c}\text { Rata-rata, } \mathrm{g} / \text { pohon/pungut } \\
\text { (Average, } \boldsymbol{g} \text { /tree/collection) }\end{array}$ & $\begin{array}{c}\mathrm{BNJ}_{\mathbf{0} 01} \\
\left.\text { (HSD }{ }_{0.01}\right)\end{array}$ \\
\hline b1 & $43,4 \mathrm{a}$ & 20,92 \\
b2 & $57,6 \mathrm{ab}$ & \\
b3 & $67,9 \mathrm{~b}$ & \\
\hline
\end{tabular}

Keterangan (Remark): Angka-angka yang diikuti oleh huruf yang sama berbeda tidak nyata (Numbers followed by the same alphabed are not significant difference) 
2014). Saat ini kebijakan mengenai penggunaan stimulan berbahan dasar asam kuat yang tidak ramah lingkungan dan membahayakan kesehatan perlu dievaluasi. Terlebih dengan semakin sadarnya manusia akan perlunya produk yang aman dan tidak mengandung bahan berbahaya (green product). Oleh karena itu, bila stimulan $\mathrm{H}_{2} \mathrm{SO}_{4}$ digunakan dalam penyadapan getah pinus, maka disarankan penggunaannya cukup dengan konsentrasi $15 \%$, dimana dengan konsentrasi tersebut sudah dapat meningkatkan hasil getah pinus yang cukup tinggi, yakni meningkat sebesar $32,72 \%$ dibandingkan dengan penyadapan tanpa stimulan.

Seiring perkembangan ilmu pengetahuan dan teknologi, teknik penyadapan pinus terus mengalami pembaharuan. Orientasi pembaharuan cara penyadapan bertujuan untuk meningkatkan hasil getah (volume dan kualitas) seoptimal mungkin namun tetap memperhatikan kelestariannya baik produk getahnya maupun pohon pinus sebagai penghasilnya (Sukadaryati., 2014). Pada penyadapan cara bor dihasilkan getah dengan kadar pengotor lebih rendah daripada cara koakan (Wiyono, 2010). Kadar pengotor dalam getah pinus bervariasi antara $7,49 \%$ untuk cara koakan menggunakan alat kedukul, 6,83\% untuk cara koakan menggunakan alat mujitech dan 3,96\% untuk cara bor (Sukadaryati., 2014). Secara visual, penyadapan dengan cara bor menghasilkan getah yang lebih bersih dan jernih dibandingkan dengan getah yang dihasilkan dari penyadapan dengan cara koakan. Pada penyadapan yang menggunakan saluran (talang) dan penampung getah yang terbuka seperti pada cara koakan dan cara riil, pengotor berupa daun pinus, serpihan kulit dan kayu dapat masuk ke dalam alat penampung dan bercampur dengan getah. Selain itu, pada cara penyadapan getah yang menggunakan alat penampung terbuka akan menyebabkan kadar terpentin getah berkurang akibat penguapan atau tumpah bersama air dari alat penampung apabila hujan lebat pada saat penyadapan berlangsung. Penyadapan cara bor menggunakan saluran getah (potongan pipa atau selang) dan wadah plastik penampung getah yang masingmasing tertutup, sehingga getah pinus yang dihasilkan lebih bersih dengan kadar terpentin lebih tinggi.

\section{KESIMPULAN DAN SARAN}

Hasil getah pinus dipengaruhi secara sangat nyata baik oleh kedalaman lubang bor maupun konsentrasi stimulan $\mathrm{H}_{2} \mathrm{SO}_{4}$. Semakin dalam lubang bor semakin banyak hasil getah pinus, demikian juga semakin tinggi konsentrasi stimulan $\mathrm{H}_{2} \mathrm{SO}_{4}$ yang digunakan semakin banyak hasil getah pinus. Peningkatan kedalaman lubang bor dari $4 \mathrm{~cm}$ menjadi $8 \mathrm{~cm}$ meningkatkan hasil getah pinus sebesar 65,96\% dan penggunaan stimulan $\mathrm{H}_{2} \mathrm{SO}_{4}$ dengan konsentrasi $30 \%$ dapat meningkatkan hasil getah pinus sebesar 56,45\% dibandingkan dengan tanpa menggunakan stimulan. Hasil getah pinus terbanyak diperoleh dari penyadapan dengan kedalaman lubang bor $8 \mathrm{~cm}$ dan penggunaan stimulan $\mathrm{H}_{2} \mathrm{SO}_{4}$ dengan konsentrasi $30 \%$, yaitu rata-rata $90,7 \mathrm{~g} /$ pohon/pungut.

\section{UCAPAN TERIMA KASIH}

Ucapan terima kasih kami sampaikan kepada Bapak Yohanis Tasi' Rumengan dan Syarifuddin yang telah ikut membantu sebagai teknisi dalam penyiapan bahan dan alat penelitian, pelaksanaan penyadapan getah pinus di lapangan dan pengukuran hasil getah pinus di laboratorium. Ucapan yang sama kami tujukan kepada Titus Dasse' petugas Kawasan Hutan Dengan Tujuan Khusus (KHDTK) Mengkendek di Kabupaten Tana Toraja yang telah memberikan pelayanan kepada tim pelaksana dan membantu dalam pelaksanaan penyadapan getah pinus sehingga penelitian ini dapat terlaksana dengan baik.

\section{DAFTAR PUSTAKA}

Bina. (2012, May). Perhutani menuju era getah bersih. Media Berita Kebutanan dan Lingkungan, 23.

Bina. (2014, May). PPCL ekspor perdana produk alphapinene ke India. Media Berita Kebutanan dan Lingkungan, 1.

Cahyono, S. A., Prakosa, D., Yuliantoro, D., \& Siswo. (2011). Produksi getah tusam pada berbagai ukuran dan jumlah koakan. Buletin HasilHutan, 7(2), 136-141. 
Esteban, L. G., Gasson, P., Climent, J. M., Palacios, P., \& Guindeo, A. (2005). The wood of Pinus canariensis and it's resinous heartwood. IAWA Journal, 26 (1),69-77.

Gaspersz, V. (1991). Metode perancangan percobaan. Bandung: CV. Armico.

Hani, A. (2009). Pengembangan tanaman penghasil hutan bukan kayu melalui perbanyakan vegetatif. Tekno Hutan Tanaman, 2(2), 83-92.

Haris, G. C. (1948). Resin acids. v. the composition of the gum oleoresin acids of Pinuspalustris. Journal of the American Chemical Society, 70(11), 3671-3674.

Harun, S. (2016). Getah pinus salah satu produk HHBK andalan. Diakses dari http:// dishut.sultengprov.go.id/2profil/63-getah-pinus-salah-satu-produkhhbk-andalan.html pada tanggal 8 Mei 2017.

Kasmudjo. (1992). Usaha stimulasi pada penyadapan getah pinus. Duta Rimba, (XVII), 15-20.

Kasmudjo. (2010). Teknologi hasil butan. Yogyakarta: Cakrawala Media.

Mirov, N. T. (1962). Compositions of gum turpentines of pines. Technical Bulletin, (1239), 1-158.

Nanos, N., Tadesse, W., Montero, G., Gil, L., \& Alia, R. (2001). Spacial stochestic modeling of resin yield from pine stands. Canadian Journal of Forestry Research, 31(7), 1140-1147.

Perhutani. (2011). Upaya meningkatkan produktivitas getah pinus menggunakan bahan yang ramah lingkungan. Diakses dari http:/www.kphcianjur.perumperhutaqni.c om pada tanggal 18 Mei 2011.

Rodrigues-Corrêa, K. C. S., Apel, M. A., Henriques, A. T., \& Fett-Neto, A. G. (2011). Efficient oleoresin biomass production in pines using low cost metal containing stimulant paste. Biomass and Bioenergy, 35(10), 4442-4448.

Rodrigues-Corrêa, K. C. S., Lima, J. C., \& FettNeto, A. G. (2017). Pine oleoresin: Tapping green chemicals, biofuels, food protection, and carbon sequestration from multipurpose trees. Diakses dari http:// onlinelibrary.wiley.com/doi/10.1002/fes3. 13/full. pada tanggal 9 Mei 2017.

Santosa, G. (2010). Pemanenan hasil hutan bukan kayu (HHBK). Diakses dari http:// members.multimania.co.uk pada tanggal 17 Februari 2011.

Satil, F., Selvi, S., \& Polat, R. (2011). Ethnic uses of pine resin production from Pinus brutia by native people on the Kazdag Mountain (Mt. Ida) in Western Turkey. Journal of Food, Agriculture \& Environment, 9(3), 1059-1063.

Sharma, K. ., \& Lecha, C. (2013). Tapping of Pinus ruxburgbii (Chir Pine) for oleoresin in Himachal Pradesh, India. Advances in Forestry Letters (AFL), 2(3), 53-57.

Shmulsky, R., \& Jones, P. D. (2011). Forest products and wood science: $A n$ introduction (6 ${ }^{\text {th }} \mathrm{ed}$ ). Chichester, West Sussex, UK.: John Wiley $\&$ Sons Ltd.

Suharisno. (2009). Grand strategy pengembangan hasil hutan bukan kayu nasional. Makalah pada Workshop Pengembangan HHBK, Yogyakarta 13 Januari 2009. Diakses dari http://www.dephut.go.id. pada tanggal 23 Agustus 2016.

Sukadaryati. (2014). Pemanenan getah pinus menggunakan tiga cara penyadapan. Jurnal Penelitian Hasil Hutan, 32(1), 62-70.

Sukadaryati., \& Dulsalam. (2015). Penggunaan stimulan cuka kayu dalam penyadapan pinus. Dalam Dulsalam, G. Pari, A. Santoso, Djarwanto, Krisdianto (Penyunt.) Prosiding Seminar Teknologi dan Inovasi Keteknikan Kebutanan dan Pengolahan Hasil Hutan dalam Menunjang Industri Pengolaban Hasil Hutan Tabun 2014 (pp. 31-42). Bogor.

Sukarno, A., Hardianto, E. B., Marsoem, S. N., \& Na'iem, M. (2013). Hubungan perbedaan ukuran mata bor terhadap produksi getah Pinus merkusii Jungh et de Vriese. Jurnal Pembangunan dan Alam Lestari, 4(1), 38-42.

Sukarno, A., Hardianto, E. B., Marsoem, S. N., \& Na'iem, M. (2015). Oleoresin production, 
turpentine yield and components of Pinus merkusii from various Indonesia provenances. Journal of Tropical Forest Science, 27(1), 136-141.

Waluyo, T. W., Wahyudi, I., \& Santoso, G. (2012). Pengaruh metode dan arah sadap terhadap produksi getah jelutung Hutan Tanaman Industri. Jurnal Penelitian Hasil Hutan, 30(4), 301-313.
Wiyono. B. (2010). Teknologi pengolahan gondorukem hidrogenesi dari hasil penyulingan getah pinus. Laporan Penelitian. Pusat Penelitian dan Pengembangan Keteknikan Kehutanan dan Pengolahan Hasil Hutan, Bogor.

Wiyono, B., Tachibana, S., \& Tinambunan, D. (2006). Chemical composition of pine resin, rosin and turpentine oil from West Java. Journal of Forestry Research, 3(1), 7-17. 